\title{
SUNFLOWER (Helinathus annuus L.) - A POTENTIAL CROP FOR ENVIRONMENTAL INDUSTRY
}

\author{
Prasad, M.N.V.
}

Department of Plant Sciences, University of Hyderabad, Hyderabad - 500 046, India

Received: October 10, 2006 Accepted: May 15, 2007

\section{SUMMARY}

Sunflower applications in phytotechnologies for the clean-up of inorganic and organic contaminants and pollutants are reviewed in this compilation. There have been several apprehensions on the application of phytoremediation technology. High bioproductivity and biomass yield are a must for the success of this strategy. The phytoextraction coefficient of sunflowers is high compared with many other species. Sunflower is a proven laboratory and field example for the emerging environmental industry. It is the most promising terrestrial candidate for metal and radionuclide removal from water. Rhizofiltration of $\mathrm{U}$ from water using sunflower plants was demonstrated in pilot-scale experiments. Sunflower accumulates $\mathrm{Cs}$ and $\mathrm{Sr}$, with $\mathrm{Cs}$ remaining in the roots and Sr moving into the shoots. Published research reports have indicated that sunflower accelerated the mineralization of 2,4,5-trichlorophenoxyacetic acid $(2,4,5-T)$ in an abandoned pasture, forest land and a floodplain. Chelator assisted metal accumulation; mycorrhizal fungi enhanced toxic trace elements accumulation and tolerance of plants are increasingly considered for remediation of mining sites.

Key words: sunflower, phytotechnology, contaminants, pollutants, Cs and Sr accumulation, environment

\section{INTRODUCTION}

There has been a general feeling among scientists that phytoremoval of environmental contaminants and pollutants is a temporary solution. However, the large body of scientific information that is available today has erased this disbelief and new areas are emerging in the field of phytotechnologies (McCutcheon and Schnoor, 2003). Sunflower (Helianthus annuus L.) is of the most promising environmental crops that is being used in diverse situations for environmental clean-up.

Sunflower has been a popular ornamental. However, in recent years its importance as environmental crop is being increasingly recognized. Dehulled seeds are used as poultry feed (Table 1). Agronomic experiments conducted on a farm research site in India using recycles organic manure from integrated farming sys- 
tem (cows, goats, poultry, etc...) have substantially increased the growth and yield (data not shown). Agronomic trials in typical Mediterranean climate where winter precipitation averages about $500 \mathrm{~mm}$, brackish water irrigated sunflower crops performance and productivity are satisfactory contributing to sustainable agriculture and also find alternative solution to drought.

Table 1: Sunflower seed oil constituents and composition

\begin{tabular}{lclc}
\hline & Whole seed & \multicolumn{2}{c}{ Fatty acid content in oil } \\
Constituent & Composition & FA & Range (\%) \\
\hline Hull & $21-27$ & Myristic & $5-7$ \\
Oil & $48-53$ & Palmitic & $3-5$ \\
Protein & $14-19$ & Stearic & $0.3-0.8$ \\
Soluble sugars & $7-9$ & Arachidic & $0.6-0.8$ \\
Fibre & $16-27$ & Oleic & $22-50$ \\
Ash & $2-3$ & Linoleic & $40-70$ \\
\hline
\end{tabular}

At a contaminated wastewater site in Ashtabula, Ohio, 4-week-old sunflowers were able to remove more than $95 \%$ of uranium in $24 \mathrm{~h}$ (Dushenkov et al., 1997a,b, 1995). Except for sunflower (Helianthus annuus) and tobacco (Nicotiana tabacum), other non-Brassica plants had phytoextraction coefficients less than one. Rhizofiltration has been employed using sunflower in a U.S. Department of Energy (DOE) pilot project with uranium waste at Ashtabula, Ohio, and on water from a pond near the Chernobyl nuclear plant in the Ukraine. Sunflowers accumulated Cs and Sr, with Cs remaining in the roots and Sr moving into the shoots (Dushenkov and Kapulnik, 2002) (Figure 1). Soils from an abandoned pasture, a forest, and a floodplain near Cincinnati, $\mathrm{OH}$, were cleaned using an association of plants comprising sunflower, timothy grass and red clover and they accelerated the mineralization of 2,4,5-trichlorophenoxyacetic acid (2,4,5-T) (Figure 1).

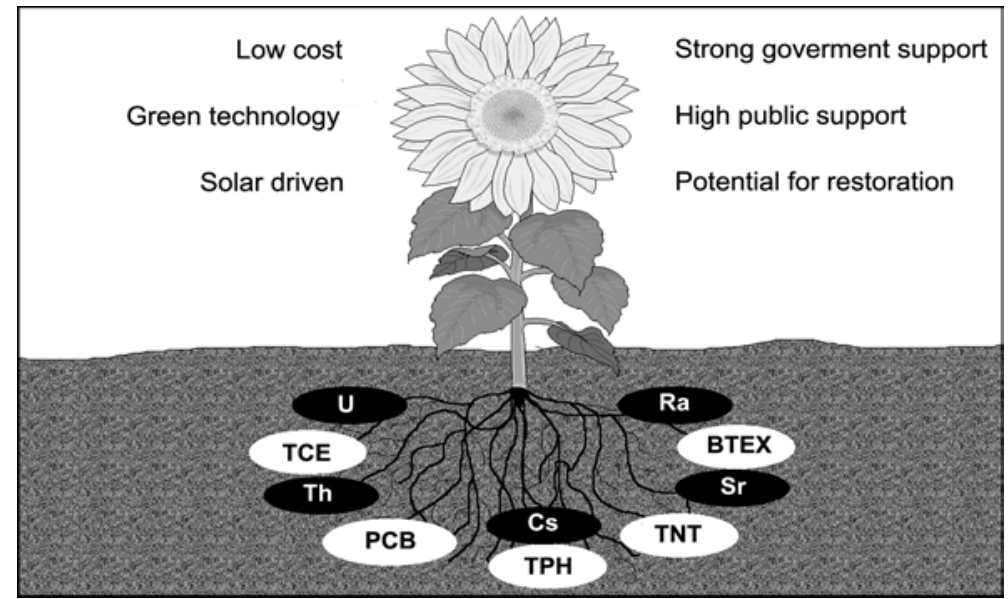

Figure 1: Sunflower as a potential environmental crops for phytotechnologies to clean-up inorganic and organic contaminants and pollutants 
Uranium (U) contamination of ground water poses a serious environmental problem in uranium mining areas and in the vicinity of nuclear processing facilities. Preliminary laboratory experiments and treatability studies indicate that the roots of terrestrial plants can be efficiently used to remove $U$ from aqueous streams (rhizofiltration). Almost all of the U removed from the water in the laboratory using sunflower plants was concentrated in the roots. Rhizofiltration technology has been tested in the field with U-contaminated water at concentrations of 21-874 $\mu \mathrm{g} / \mathrm{l}$ at a former U processing facility in Ashtabula, $\mathrm{OH}$. The pilot-scale rhizofiltration system provided final treatment to the site source water and reduced $U$ concentration to $<20 \mu \mathrm{g} / \mathrm{l}$ before discharge to the environment. System performance was subsequently evaluated under different flow rates permitting the development of effectiveness estimates for the approach (Dushenkov et al., 1997a,b).

Table 2: Application of sunflower in phytotechnologies for clean up of heavy metals, radionuclides and organic contaminants and pollutants (in reverse chronology)*

\begin{tabular}{ll}
\hline Lab or field study & Reference \\
\hline Soil-to-plant transfer factors of natural uranium and radium & Rodriguez et al., 2006 \\
Comparative effect of $\mathrm{Al}, \mathrm{Se}$, and Mo toxicity on $\mathrm{NO}_{3}$ - assimilation & Ruiz et al., 2006 \\
Phytoextraction of excess soil phosphorus & Sharma et al., 2006 \\
Trace metal accumulation, movement, and remediation in soils receiving & Sistani et al., 2006
\end{tabular}
animal manure

Accumulation of radioiodine from hydroponic system

${ }^{137} \mathrm{Cs}$ and ${ }^{90} \mathrm{Sr}$ uptake

Soudek et al., 2006a

The influence of EDDS on the uptake of heavy metals in hydroponic

Soudek et al., 2006b

system

Removal of polycyclic aromatic (PAH) hydrocarbons from contaminated Gong et al., 2005a

soils

and 2006

Dissolution and removal of PAHs

Gong et al., 2005b

Leaching and uptake of heavy metals in EDTA-assisted phytoextraction Chen et al., 2004

process

Response of antioxidants grown on different amendments of tannery Singh et al., 2004

sludge: metal accumulation potential

${ }^{137}$ Cs uptake

EDTA and citric acid role on phytoremediation of $\mathrm{Cd}, \mathrm{Cr}$, and $\mathrm{N}$

Soudek et al., 2004

Accumulation of copper

Turgut et al., 2004

Lin, 2003

EDTA-assisted heavy-metal uptake in a association with poplar at a long- Liphadzi et al., 2003

term sewage-sludge farm

Trace element and nutrient accumulation two years after the Aznalcollar Madejon et al., 2003

mine spill, Spain

Uptake and translocation of plutonium in hydroponics

Lee et al., 2002a

Uptake of plutonium from soils - a comparative study with Brassica juncea Lee et al., 2002b

Mycorrhizal fungi enhanced accumulation and tolerance of chromium Davie et al., 2001

Accumulation of heavy metals in a association with Sorghum as affected Murillo et al., 1999

by the Guadiamar spill.

Removal of $\mathrm{Cd}^{2+}, \mathrm{Cr}^{6+}, \mathrm{Cu}^{2+}, \mathrm{Mn}^{2+}, \mathrm{Ni}^{2+}$ and $\mathrm{Pb}^{2+}$ in miniature rhizofil- Dushenkov et al., 1997a

tration batch experiments

Rhizofiltration of $U, S r$ and Cs using 4 week-old plants

Dushenkov et al., 1997b

* =the list may not be exhaustive 
Terrestrial plants are thought to be more suitable for rhizofiltration because they produce long, more substantial, often fibrous root systems with large surface area for metal sorption. Sunflower (Helianthus annuus L.) removed $\mathrm{Pb}$ and $\mathrm{U}$ (Dushenkov et al., 1997a), ${ }^{137} \mathrm{Cs}$, and ${ }^{90} \mathrm{Sr}$ (Dushenkov et al., 1997b) from hydroponic solutions. Rhizofiltartion was found to be appropriate for the cleanup of $\mathrm{Sr}$ from surface water using hydroponic and field experiments. A pond near the Chernobyl nuclear reactor was phytoremediated with sunflowers and their roots accumulated large quantities of radionuclides with bioaccumulation coefficient greater than 600 for both shoots and roots (Negri and Hinchman, 2000). The role of synthetic chelates and mycorrhizal fungi phytoremoval of contaminats has been evaluated in a number of investigations (Table 2).

\section{CONCLUSIONS}

The frequently asked questions (mechanisms, diversity, efficacy and safety related):

- How does phytoremediation works?

- Disagreement or doubts among scientists about environmental clean-up?

- Often, some say it is only a temporary solution?

- How are plants selected?

- How to dispose of the plants contaminated in the process of phytoremediation?

- Will phytoremediation work on every contaminated/polluted site?

- How do we know that phytoremediation is really working?

- Is the biomass produced from the exercise of phytoremediation usable?

All these questions have satisfactory answers and phytotechnologies today have reached the site from lab-pilot scale and field trials (Figures 2-4).

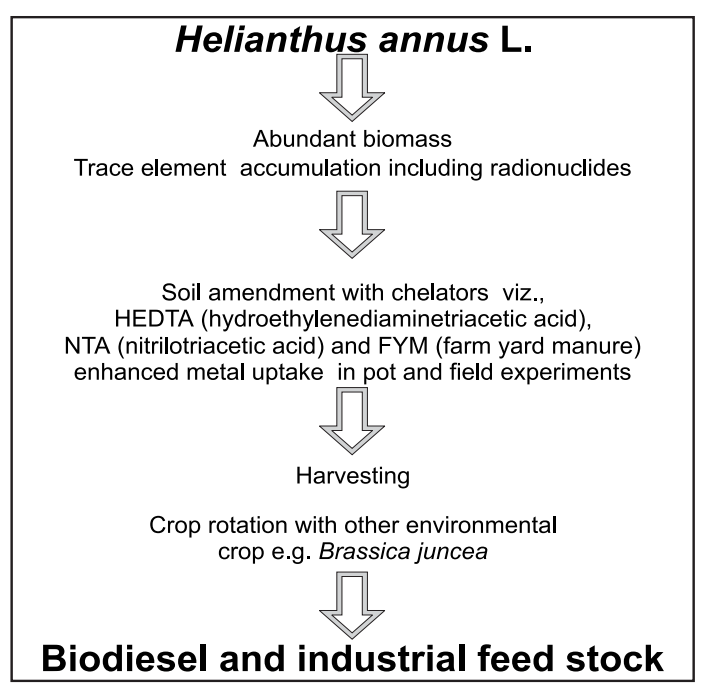

Figure 2: Sunflower as an environmental crops for production of biodiesel through cultivation on metal contaminated soils 


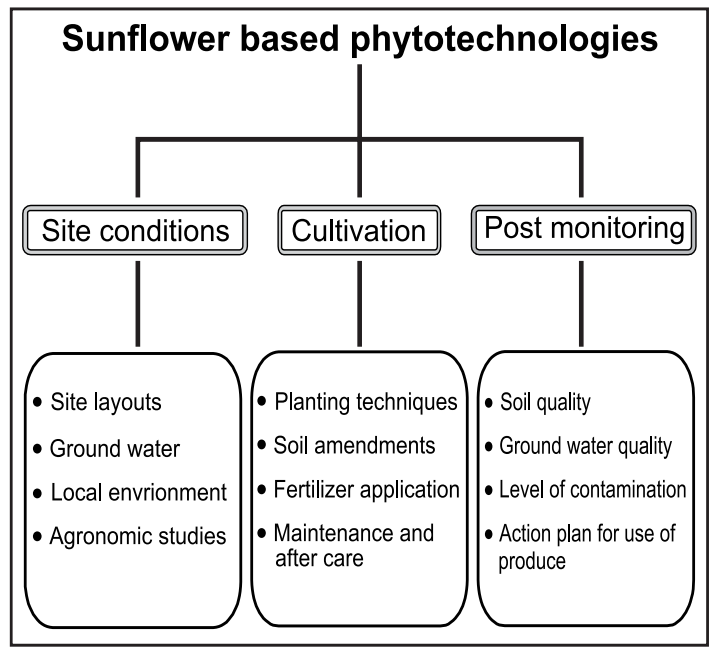

Figure 3: Assessment and applicability of sunflower as an environmental crops for phytotechnologies

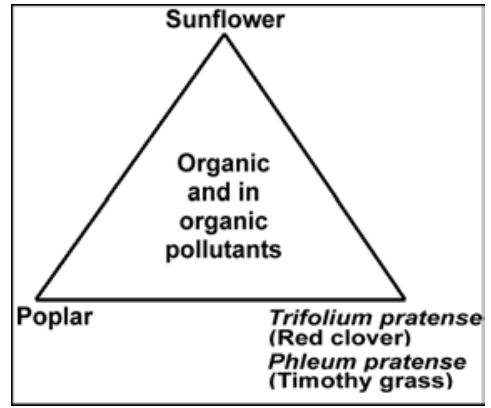

Figure 4: Long-term phytotechnological applications of sunflower in association with tree crops, legumes and grasses for the clean up of sewage sludge, heavy metals, radionuclides and organic contaminants and pollutants

\section{REFERENCES}

Chen, Y., Li, X. and Shen, Z., 2004. Leaching and uptake of heavy metals by ten different species of plants during an EDTA-assisted phytoextraction process. Chemosphere 57: 187-196.

Davies, Jr. F.T., Puryear, J.D., Newton, R.J., Egilla, J.N. and Grossi, J.A.S., 2001 . Mycorrhiza fungi enhance accumulation and tolerance of chromium in sunflower (Helianthus annuus L. ). Journal of Plant Physiology 158: 777-786.

Devi, P. and Rani, S., 2002 Agrobacterium rhizogenes induced rooting of in vitro regenerated shoots of the hybrid Helianthus annuus $\times$ Helianthus tuberosus. Scientia Horticulturae 93: 179-186.

Dushenkov, S., Kapulnik, Y., 2002. Phytofilttration of metals. In: I. Raskin and B.D. Ensley (Eds), Phytoremediation of Toxic Metals: Using Plants to Clean Up the Environment. John Wiley and Sons, Inc. New York. Pp 89-106.

Dushenkov, S., Kapulnik, Y., Blaylock, M., Sorochisky, B., Raskin, I. and Ensley, B., 1997a. Phytoremediation: A novel approach to an old problem. In: D.L.Wise (Ed), Global Environmental Biotechnology, Elsevier Science B.V. Amsterdam. Pp. 563-572.

Dushenkov, S., Vasudev, D., Kapulnik, Y., Gleba, D., Fleisher, D., Ting, K.C., Ensley, B., $1997 \mathrm{~b}$. Removal of uranium from water using terrestrial plants. Environ. Sci. Technol. 31: 34683474 .

Dushenkov, V., Nanda Kumar, P.B.A., Motto, H. and Raskin, I., 1995. Rhizofiltration: The use of plants to remove heavy metals from aqueous streams. Environ. Sci. Technol. 29:12391245.

Gong, Z., B.-M., Alef, W.K. and Li, P., 2005a. Influence of soil moisture on sunflower oil extraction of polycyclic aromatic hydrocarbons from a manufactured gas plant soil. Science of the Total Environment 343: 51-59.

Gong, Z., B.-M., Alef, W.K., Li, P. and Qixing Zhou, 2006. Removal of polycyclic aromatic hydrocarbons from manufactured gas plant-contaminated soils using sunflower oil: Laboratory column experiments. Chemosphere 62: 780-787.

Gong, Z., Alef, W.K., Wilke, B.M., and. Li, P., 2005b. Dissolution and removal of PAHs from a contaminated soil using sunflower oil. Chemosphere 58: 291-298. 
Lee, J.H., Hossner, L.R., Attrep Jr., M. and Kung, K.S., 2002. Uptake and translocation of plutonium in two plant species using hydroponics. Environmental Pollution 117:61-68.

Lee, J.H., Hossner, L.R., Attrep Jr., M. and Kung, K.S., 2002. Comparative uptake of plutonium from soils by Brassica juncea and Helianthus annuus. Environmental Pollution 120 : 173-182.

Lin, J., Jiang, W. and Liu, D., 2003. Accumulation of copper by roots, hypocotyls, cotyledons and leaves of sunflower (Helianthus annuus L). Bioresource Technology 86: 151-155.

Liphadzi, M.S., Kirkham, M.B., Mankin, K.R., Paulsen, G.M., 2003. EDTA-assisted heavy-metal uptake by poplar and sunflower grown at a long-term sewage-sludge farm. Plant and Soil 257: 171-182.

McCutcheon, S.C. and Schnoor, J.L., (eds) 2003. Phytoremediation - Transformation and Control of Contaminants. Wiley Interscience. pp. 985.

Madejon, P., Murillo, J.M., Maranon, T., Cabrera, F. and Soriano, M.A., 2003. Trace element and nutrient accumulation in sunflower plants two years after the Aznalcollar mine spill. The Science of the Total Environment 307: 239-257

Murillo, J.M., Marañon, T., Cabrera, F., López, R., 1999. Accumulation of heavy metals in sunflower and sorghum plants affected by the Guadiamar spill. The Science of the Total Environment 242:281-292.

Negri, M.C. and Hinchman, R.R., 2000. The use of plants for the treatment of radionuclides. In: I. Raskin and B.D. Ensley (Eds), Phytoremediation of Toxic Metals: Using Plants to Clean Up the Environment. John Wiley and Sons, Inc. New York. Pp 107-132.

Rodriguez, P.B., Tome, F.V., Fernandez, M.P. and Lozano, J.C., 2006. Linearity assumption in soil-to-plant transfer factors of natural uranium and radium in Helianthus annuus $\mathrm{L}$. The Science of the Total Environment 361:1-7.

Ruiz, J.M., Rivero, R.M. and Romero, L., 2006. Comparative effect of Al, Se, and Mo toxicity on $\mathrm{NO}_{3}^{-}$assimilation in sunflower (Helianthus annuus L.) plants. Journal of Environmental Management, In press.

Santos, C.V, Pereira, A., Pereira, S. and Teixeira, J., 2004. Regulation of glutamine synthetase expression in sunflower cells exposed to salt and osmotic stress. Scientia Horticulturae 103: 101-111.

Sharma, N.C., Starnes, D.L. and Sahi, S.V., 2006. Phytoextraction of excess soil phosphorus. Environmental Pollution, In press, Corrected proof available at http://www.sciencedirect.com online, from 10 August 2006.

Singh, S., Saxena, R., Pandey, K., Bhatt, K. and Sinha, S., 2004. Response of antioxidants in sunflower (Helianthus annuus L.) grown on different amendments of tannery sludge: its metal accumulation potential. Chemosphere 57: 1663-1673.

Sistani, K.R. and Novak, J.M., 2006. Trace metal accumulation, movement, and remediation in soils receiving animal manure, In: Prasad, M.N.V., Sajwan, K.S, and Ravi Naidu (eds) Trace Elements in the Environment: Biogeochemistry, Biotechnology and Bioremediation. pp. 689-706. CRC Press. Boca Raton.Taylor and Francis Group.

Soudek, P., Tykva, R., Vankova, R. and Vanek, T., 2006. Accumulation of radioiodine from aqueous solution by hydroponically cultivated sunflower (Helianthus annuus L.) Environmental and Experimental Botany 57: 220-225.

Soudek, P., Tykva, R. and Vanek, T., 2004. Laboratory analyses of ${ }^{137} \mathrm{Cs}$ uptake by sunflower, reed and poplar. Chemosphere 55:1081-1087.

Soudek, P., Valenova, S., Vavrikova, Z. and Vanek, T., 2006. ${ }^{137} \mathrm{Cs}$ and ${ }^{90} \mathrm{Sr}$ uptake by sunflower cultivated under hydroponic conditions. Journal of Environmental Radioactivity, 88: 236-250.

Tandy, S., Schulin, R. and Nowack, B., 2006. The influence of EDDS on the uptake of heavy metals in hydroponically grown sunflowers. Chemosphere 62: 1454-1463.

Turgut, C., Pepe, M.K. and Cutrigh, T.J., 2004. The effect of EDTA and citric acid on phytoremediation of $\mathrm{Cd}, \mathrm{Cr}$, and $\mathrm{Ni}$ from soil using Helianthus annuus. Environmental Pollution 131: 147-154. 


\title{
GIRASOL (Helianthus annuus L.) - CULTIVO POTENCIAL PARA LA INDUSTRIA ECOLÓGICA
}

\author{
RESUMEN
}

En este Resumen se considera la aplicación de girasol en las fitotecnologías destinadas a eliminación de contaminantes y polutantes inorgánicos y orgánicos. En el pasado había ciertos temores en cuanto a la aplicación de la tecnología de fitoremediación. Alta bioproductividad y alto rendimiento de la biomasa, son obligatorios para el éxito de esta estrategia. El coeficiente de esta fitoextracción es más alto en girasol que en muchos otros cultivos. El girasol es un ejemplo probado en las condiciones de laboratorio y del campo para una nueva industria ecológica. Él es el candidato de más perspectivas entre las plantas terrestres para eliminación de metales y radionucleidos del agua. El éxito de la rizofiltración de uranio desde el agua, con ayuda de las plantas de girasol, fue confirmado en la escala experimental. El girasol acumula Cs y Sr, así que Cs se queda en la raíz, mientras que Sr se transloca en los brotes. Los datos de investigación publicados, indican que girasol acelera la mineralización del cido 2,4,5-triclorofenoxi-acético $(2,4,5$-T) en los suelos de pasto abandonado, del terreno boscoso y pantanoso. La acumulación de metales por medio de helatos, aumentada acumulación de microelementos tóxicos mediante los hongos micorrizas y la tolerancia de plantas se consideran cada vez más y cada vez más seriamente, en la fitoremediación de escoriales.

\section{LE TOURNESOL (Helianthus annuus L.) CULTURE POTENTIELLE DANS L'INDUSTRIE ÉCOLOGIGUE}

\section{RÉSUMÉ}

Cet article rend compte des applications du tournesol dans les phytotechnologies d'élimination de contaminants et de polluants inorganiques et organiques. Dans le passé, il y avait certaines craintes au sujet de l'application de la technologie de phytoremédiation. Une grande bioproductivité et un grand rendement de la biomasse sont indispensables au succès de cette stratégie. Le coefficient de phytoextraction des tournesols est plus élevé que celui de toute autre culture. Le tournesol est un exemple éprouvé en laboratoire et sur le terrain pour l'industrie écologique naissante. Il est le candidat terrestre le plus prometteur parmi les plantes pour l'élimination des métaux et des radionucléides de l'eau. Le succès de la phytofiltration de l'uranium de l'eau à l'aide du tournesol a été démontré sur une échelle expérimentale. Les données de recherche publiées montrent que le tournesol accélère la minéralisation de l'acide 2,4,5-trichlorophenoxyacétique $(2,4,5-\mathrm{T})$ dans les pâturages abandonnés et dans les sols forestiers et marécageux. L'accumulation de métal par chélateur, l'augmentation de micro-éléments toxiques par mycorhizes et la tolérance des plantes sont observées de plus en plus sérieusement pour la remédiation des sols stériles. 
